\title{
Successful Social Media Advertising Activities for Micro, Small and Medium Enterprises
}

\author{
${ }^{1}$ Joko Suryono , ${ }^{2}$ Nuryani Tri Rahayu, ${ }^{3}$ Purwani Indri Astuti, ${ }^{4}$ Nunun Tri Widarwati \\ 1,2 Communication Science Department, University of Veteran Bangun Nusantara Sukoharjo, Indonesia. \\ ${ }^{3,4}$ English Program, University of Veteran Bangun Nusantara Sukoharjo, Indonesia. \\ E-mail: 1jokowignyo@univetbantara.ac.id, ${ }^{2}$ nuryani_tr@yahoo.com, ${ }^{3}$ indripuspo@univetbantara.ac.id \\ ${ }^{4}$ nununtriwidarwati@gmail.com
}

\begin{abstract}
In Indonesia, MSMEs are a business group that is a mainstay of economic activity that is able to support most of its citizens. Economic development in Indonesia depends on the development and improvement of the capacity of MSMEs. MSMEs will be helped by improving their marketing performance through social media advertising. The use of social media advertising will create easy, cheap and fast access. Social media advertising can be used by companies to distribute advertisements and create awareness for customers. The research method in this research uses descriptive qualitative method. Data collection techniques use in-depth interviews with SMEs, library research, and focus group discussions involving advertising experts, academics, and social media experts. The data source in this study is MSMEs, advertising practitioners, communication science academics. Data analysis is carried out inductively and interactive analysis methods. The results of this study are 1) successful social media to advertise for MSMEs are websites, blogs, Google, Youtube, Whatsapp, Facebook, Instagram 2) Advertising content on social media must pay attention to ad photography, watermarks, simple videos, videos as much as possible, professional videos, use of keywords, use of endorsements and testimonials 3) Awareness, consumer considerations in making purchases occur in a social media ecosystem that is interrelated and interact with each other
\end{abstract}

Keywords: Social Media, Social Media Advertising Content, SMEs

\section{INTRODUCTION}

MSME is a business group that is a mainstay of economic activity in any country and is able to support most of its citizens. UMKM (Micro, Small and Medium Enterprises) in Indonesia is an economic business that is able to support and support the lives of most of its citizens, numbering more than 250 million. The number of business sectors in this country is very large, namely micro businesses totaling $57,189,393$ units (98.77\%), small businesses 654,222 units $(1.13 \%)$, medium businesses 52,106 units $(0.09 \%)$, the rest are large businesses5. 066 Units (0.01\%) (Sutyowati, 2016: 3).

MSMEs as the foremost forefront of economic progress need to be empowered and their capacity developed. Capacity building is a process of increasing the ability of individuals, groups and networks. In this case, the notion of capacity is not passive but is a dynamic and sustainable process (Mardikanto, 2010: 68). Capacity building has contained a process to improve its capabilities and existence (Balcazar, Yolanda Suarez., Fabricio E. Balcazar, Tina Taylor Ritzler, 2008).

Capacity building is an effort related to the development of knowledge, skills to be able to improve the quality of personal, organizational and business. In developing business capacity, it will be directly linked to a network of mutually beneficial partnership cooperation (Mardikanto, 2010: 69). The development of partnership cooperation is important. 
Development of partnerships related to marketing communication activities. In alternative marketing communication approaches, MSMEs use a network of personal contacts, social networks, business and industrial networks (Gilmore et al., 2001: 5)

One alternative marketing
communication method to spur marketing acceleration is through social media advertising. Social media advertising utilizes internet-based information technology (Barnes, 2014: 3). Social media advertising is the process of delivering creative messages created by creative groups through the stage of extracting ideas, delivered to segmented audiences, through planned social media selection, which is able to influence, convince, change perceptions, attitudes, and actions of the audience. In advertising activities we need people who always have big, unique ideas to distinguish their work from the work of others. The function of advertising is to inform the audience about a particular product, convincing about the benefits of the product.

In daily life, in trading activities, social media advertising is present in the midst of society. The role of media advertising has become the dominant communication message and is able to provide awareness about a product, convince the benefits of a product and persuade potential buyers (Suryono, J et al. (2019a), stimulate competition, create demand and encourage the development of new products, accelerators the heart of a liberal economy (Tungate, 2007: 14) Advertising has become a tool for creating a positive brand image of a brand, advertising has become a part of the tool for trading the commodity sign that serves as a messenger for promotion, strengthening and adding to the brand's image ( Suryono, J et al., 2019b).

Nowadays, socialmediahave played themselves as advertising media needed by businesses. Social media has the ability as a medium for delivering messages that is fast, inexpensive with a broad reach and is able to connect one human being with another human being, one organization with another organization. Changes in the development of communication and information technology gave birth to social media that is able to connect one human being with another human being. Social media has become an amazing medium of interaction. Communication between people across islands, across oceans, across continents in just seconds (Krishnamurthy, 2018: 2). Discussions between sellers and buyers easily occur on social media. Social media has become one of the most prominent promotional tools in business and is used as a key platform to create awareness and support for a product (Govender, 2013: $4)$. The increasing use of social media by customers around the world provides opportunities for small businesses to improve their online platforms and profiles (Govender, 2013: 6).

Through social media, MSMEs can advertise their products faster at much lower costs. Social media has revolutionized the way companies advertise and market goods and services. By using social media, MSMEs can advertise and launch promotions in new ways, carry out ad campaigns quickly and easily, and increase consumer involvement (Mon, 2013: 43). Besides that social media is very effective to increase the spirit of the value of a brand (brand equity). The presence of a brand on social media attracts consumers' attention, generates brand awareness and familiarity, and allows marketers to reach consumers directly (Boyd \& Ellison, 2008: 3).

Discussions on social media advertising have been studied in various books and previous studies. Among 
them is the research of Advertising on Social Media and Benefits for Brands by Ohajionu \& Mathews. In the study, it was concluded that the use of social media for advertising by companies around the world continues to increase. Many companies now have Facebook pages, Twitter accounts, blogs. Various social media companies can use in advertising to improve services and quality for customers and increase profits.

In addition there is a previous study entitled The Right Potential Advertising Media Model Targeting SME Leading Products by Joko Suryano and Purwani Indri Astuti, The study found that in creating advertising messages on social media high creativity, great ideas, both ad text and illustration (photo) of the ad. Friendship communities in social media are ways and strategies to determine the right target market (Suryono, Joko, 2013: 17).

Another study entitled the internet and advertising by Moustofa concluded that the internet had made a revolution of knowledge, production, storage and distribution. A few clicks of the finger on the keyboard, users can save hours searching for ad choices for shopping at the store. Online trademarks with the prefix (e-) such as e-library, e-business, e-health, etc., are increasingly becoming part of the advertising vocabulary. Some social and professional networks collect user profiles for sales and advertising purposes (Moustafa, 2016: 293).

From some of the studies that have been presented above, the urgency of this research is to discuss the importance of social media advertising for MSMEs, which consists of selecting fast and inexpensive social media for MSMEs in advertising their products or brands and MSME capacity in creating inexpensive advertising content. and interesting. More centrally this research aims to produce: 1) an effective description of social media for
MSMEs in advertising, 2) a description of advertising content on social media that is appropriate for MSME products.

\section{METHOD}

The title of this research is Successful Social Media Advertising for SMEs. The object of his research is SMEs: Power Cat Cats, Mitshop.Id Bag Sales, Motorcycle Accessory Dses, social media and social media content. Successful Social Media Advertising Research for MSMEs uses a qualitative descriptive study. Descriptive qualitative research seeks to describe a phenomenon in detail, detail and in full. Delivered by qualitative descriptive research Sutopo is a study that leads to a detailed and indepth description of the condition portrait of what happens according to what is in the field of study (Sutopo, 2006: 111). Added by Denzin and Lincoln, qualitative descriptive is a method for describing and explaining the activities or objects under study relating to the study of phenomena in more detail or differentiating them from other phenomena (Denzin \& Lincoln, 1994: 3).

Data collection techniques used were in-depth interviews with informants of MSMEs, observation of passive roles, literature studies, and focus group discussions involving advertising experts, academics, and social media experts. Data analysis is carried out inductively and the method of interactive analysis, the interactive model is a data analysis process consisting of three main components, namely data reduction, data presentation and drawing conclusions/ verification which is a cycle process.

\section{RESULTS AND DISCUSSION Social Media Advertising}

Advertising world now, enlivened by the development of social media communication technology. Social media advertising is a communication process 
that involves advertising creators, creative messages, social media and the target audience. Delivered by Tono Dzaky, Creative Director at Tono Dzaky Creative Boutique, Marketing and Advertising, "the process of communication using social media must know who we are talking to (target audience), using special language, displaying unique images".

The character of the target audience has changed, not like when we were in the old media era. The customer has changed the behavior of media exposure. Online communities have a great influence on strategies to reach consumers. Consumers have the absolute right to select messages, both personally and with their communities through a process of mutual trust, mutual reference and shared social views. Interesting and relevant products will attract people's interest through conversation in this community (Springer, 2007: 277).

In planning an online advertising campaign to achieve a strong impression, advertisers must cleverly balance their target market and message frequency. How many times the advertisement was exposed and how much it would cost (Plummer, Joseph, Steve Rappaport, Taddy Hall, 2001: 33).

\section{Instagram Advertising}

When we talk about the target audience of young people, to deliver advertising messages, SMEs often use Instagram social media. The target audience of adolescents likes to use Instagram as a medium to fulfill their lifestyle pleasure and improve their social status. Teenagers claim to use Instagram to meet current lifestyle information needs. They are happy with fun information (Prabowo, 2017: 266).

Visual language often appears on Instagram as a medium that represents teenagers, who are just happy to admire themselves and other teenagers. Instagram is a visual media that relies on quality photos to attract buyers. Buyers like photos that are artistic, beautiful, character, passionate, have strength and depth. The strength of the product photos will be able to persuade prospective buyers to sell a new trendy product. Product photos will increasingly have a strong magnetic force if the product is worn by public figures or often referred to as celebrity endorsers.

On Instagram social media, one of the strategies to increase the value of a brand is through a celebrity endorsement strategy. Tono Dzaky, Creative Directorate Tono Dzaky Creative Boutique, Marketing and Advertising said, "Instagram is a very effective social media for advertising MSME products such as clothes, bags, the shoes. Instagram celebrities are celebrities who display typical features and attributes of certain products to increase their appeal to the public. For example, celebrity sister Oki Setianadewi (Ria Ricis) has millions of followers. If the celebrity poses with a product such as clothes, cosmetics, celebrity visuals when using certain products, will be able to enhance the brand image of a product, the impression will be displayed forever.

Furthermore, Paramitha MSME Mitshop.id actors said, "social media used for selling is Instagram account mitshop.id by displaying photos of merchandise bags with various models and endorsement strategies. Bags of mitshop.id merchandise are worn by some famous soap opera artists such as super pubescent Mauren Daryanani, super pubescent Sarah Tuff, Elina Joerg artists, Zahwaqilah artists in soap operas on the pilgrimage. With a variety of interesting poses, the endorsement activities can increase the number of followermitshop. id".

Endorsement strategies are also identical personal branding that serves to 
validate, support and strengthen the value of a brand. As in the research of Yuliani \& Dida (2018), entitled Personal Branding Celebrities and Online Shop Business. In this research found about personal branding Zaskia Adya Mecca as a soap star and Indonesian film star, Zaskia Adya Mecca wearing Muslim women's clothing in social media on Instagram and website that aims to promote the products owned by Zaskia Adya Mecca to fans and consumers to be interested in buying Muslim women's clothing at social media on Instagram and on the website that aims to promote the products owned by Zaskia Adya Mecca to fans and consumers to be interested in buying products from Muslim women on social media on Instagram and the website. the product it sells. Public figures in the community turned out to be very influential on consumer confidence in certain products. Endorser artist will create a sense of pride in consumers, the product to be purchased will position itself like a famous artist. Celebrity endorsers become brand spokespersons so that they are fast in the minds of consumers and can be used to represent targeted market segments. (Royan, 2004: 12).

\section{Youtube Advertising}

YouTube has made major changes that have an impact on advertisers to invest in the field of online advertising and has become the easiest free advertising option for MSMEs. Holmbom delivered a lot of potential and benefits gained by developing YouTube channels. With the characteristics of audio-visual offerings owned by YouTube, marketers can present the message of advertising products or brands through videos that are done amateurs and professionals (Holmbom, 2015: 2).

With the limited capabilities possessed by MSMEs, MSMEs cannot yet produce images and sounds like commercial television. There are two different opinions from the video ad serving on YouTube for MSMEs. The first, told by Suryadin Loadang, Online Sales Lecturer, "to advertise on YouTube, with the limited capabilities of MSME, there is a very simple and easy way that can be used, namely enough by displaying the name of the item to be sold, for example salted fish and writing the HP or WA number, then upload it on youtube. With google search, people who need certain product items will contact the HP or WA number. To get on the first page on YouTube if our keywords are unique and we make as many as possible, people will easily find our merchandise. "“

A different opinion was conveyed by Tono Dzaky, Creative Director at Tono Dzaky Creative Boutique, Marketing and Advertising, "Advertising on Youtube requires the ability to make reliable videos. Amateur video advertisements will make the product look cheap. The company's product image can be seen from the video display, clean images, attractive ad stars, elegant clothing and crystal clear sound quality. Advertising stars should not be modest, only wearing flip-flops, t-shirts in, disheveled hair, without makeup ".

Poor visuals will show that the product being sold is cheap. The audience wants to see something beautiful, an ad with a professional look and execution. As said by Dru in Tungate (2007) consumers always enjoy good advertisements, quality advertising products will always find an appreciative audience. Great advertisers have high respect for consumers and understand consumers by creating ads that have a strong appeal. Advertisers and advertisements are far more respectful of consumers than other industries.

One of the attractions of video advertisements is that they contain an element of entertainment. In addition to containing the beauty and attractive elements, there are important elements that must be considered in making ads 
on YouTube, which contains elements of entertainment. Many people spend time surfing to find interesting entertainment sites. Interesting entertainment usually involves community participation (community power), presenting content with the latest trends, news, funny parodies (Davis, Harold, 2006: 5).

\section{Blog Advertising}

Blogs have become one source of inspiration and information about certain topics for readers. Blog writers have the opportunity to write and present images in accordance with what is desired. Personal blogs have several independent communication methods, as a communication style visualized in a personal way, as a means of representation, self-expression, selfdemonstration, which has individual meanings and unique experiences. Some communication styles are applied in blogging based on personal values and motivation to interact with readers as a specific communication strategy. Communication activities in blogs are influenced by the value of a brand with consumers (Bunina, 2013: 2).

The blogger's strategy in enhancing brand image through an experiential marketing approach is by creating an emotional audience through sharing experiences. As stated by Rika Verry Kurniawan, Automotive Blogger, rikaverrykurniawan.com, "The strategy of developing a particular brand is carried out by involving the blogger's experience through an activity. For example, oil marketers, inviting 1000 Bloggers to Bali to see and try big motor vehicles through touring activities. Driving comfort and influence on fuel efficiency will be part of Blogger's content presentation. 1000 Bloggers in their writings will give positive appreciation, support and invite readers in their blog accounts to use oil products that are used by the big motor.
Writing testimonials and advertorial is very thick in the concept of writing on the blog “.

Bloggers build long-term relationships and friendships based on quality interaction, which aims to find readers with the same passion and experience. Communication sharing experiences through blog mode is an important activity to build community. Bloggers strive to apply certain communication methods for the purpose of self-fulfillment, increase the value of the contents of messages and build the value of relationships.

A web blog is a form of web application that is often referred to as a blog containing various kinds of writings (which are loaded as posts or blog articles) on a public web page (blog template). Like an online magazine that at any given time informs specific messages related to products or services.

Blogs are widely used as UMKM advertising media, which contains information or actual coverage placed on the first sequence, which is then followed by old information. Blog sites are accessed by readers or viewers according to interesting topics and communication goals of the blog owner. As told by Tono Dzaky, Creative Director at Tono Dzaky Creative Boutique, Marketing and Advertising, "I have a Power Cat branded cat food client, one of the social media used by Power Cat is Blogspot. The Power Cat Blogspot is used to inform you about Power Cat cat food features (why cat food should be halal), event information such as the Ada Ada Ada Story story, Riding with the Cat Power Bike, interactive discussions between cat keepers and cat keepers, between cat keepers and cat food entrepreneurs, the presence of child education leaders. "In addition to being used as a blog media to convey information, it can be used for interactive discussions, which take place 
continuously.

Dozier, Grunig and Grunig in Thornley, refer to it as "two-way communication," blog viewers are encouraged to combine communication to not only lead to their buying behavior but also to inspire everyone who follows the blog's words (Thornley, 2014: 1)

\section{Whatsapp Advertising}

Smartphone applications are increasingly popular for sharing information through private networks, community networks, which serve as advertising media for national and MSME companies. The use of smartphone applications such as WhatsApp has contributed greatly, positively impacted and helped develop online businesses. Through the WhatsApp application Information to consumers can be reached quickly and get fast responses too.

Through WhatsApp social media advertising activities, home-based companies can deliver online content to prospective or loyal buyers. Customers can view their online shopping products online and buy products from their smartphone applications. Hwang in Jamaluddin et al said that innovative technology through smartphone applications can help business development throughout the world (Jamaluddin et al., 2014: 2).

WhatsApp as a social media where people gather, communicate, deliver messages in a variety of things is currently experiencing great development, used by SMEs for marketing activities and delivering advertising messages. Oji et al (2017: 1) revealed that social media was quite effective as a marketing tool for MSMEs, WhatsApp was considered the most effective, followed by Facebook and Twitter. Social media can be used as an alternative advertising strategy for small businesses. SMEs can assess and maximize the capabilities offered through social media platforms.
WhatsApp has emerged as the largest marketing media and business communication tool. The message application is simple, able to connect many people around the world and makes it easy for business communication activities. WhatsApp dominates the messaging market in several countries, it can be used as a low-cost global marketing tool.

WhatsApp Network Tools through Broadcast Lists, send messages to a number of contacts at once, one message can be sent to one to hundreds of WhatsApp users. A business person can use the WhatsApp network freely and for free. Network members can use telephone and mobile services. WhatsApp is a cross-platform solution that works with a variety of cellphones including Android, iPhone, Blackberry, Windows Phone and some Nokia products. This network can be used to advertise a product through digital messages such as videos, music, recordings, books or written documents in PDF format.

WhatsApp social media can be used to build private networks and group chats. In Indonesia, WhatsApp was not used to advertise for the first time but was used as a personal chat and a group chat. Many things discussed in the chat include stories of school history, social, social, cultural, political and religious life.

As explained by Agung Wijanarko, Chief Marketing Officer of the MSV Picture University of AMIKOM Yogyakarta, "WhatsApp by its developers is not first used as a medium for advertising placements, WhatsApp is used as a media for broadcasting certain messages. But with its platform, social media as a community media is finally used to trade, offer each other goods.

Today WhatsApp's potential is used as a business tool. WhatsApp is now an excellent inexpensive tool for transmitting business and professional information. 
Important data such as sales plans, business strategies, confidential client communications, contracts, financial records, sales reports and accounting data can be sent via WhatsApp at no charge.

The potential of WhatsApp is widely used by SMEs in Indonesia. Many WhatsApp groups have sprung up which are used as advertising media to deliver business messages. Like the WhatsApp Group Ad Exchange 2nd Motor Car Group that offers used cars and motorcycles. Central Java UMKM promotion which contains advertisements about the sale of robe, ads for caterpilar safety shoes, ads for Tag Heur Tecno hours, tickets ordering ads. Halal online marketplace, which contains advertisements about children's sports shoes, travel recorder cameras, double shoe racks, date palm dates, Date Crown Khallas dates, sling hits, Islamic encyclopedias, Gajah Duduk sarongs and Wadimor. Our Smile, which contains advertisements about powerful diabetes recipes, Mimo Electric massage tools, land plots, pants, seminars and workshops.

\section{Facebook Advertising}

Now Facebook has become an easy, inexpensive, safe and convenient way to develop advertising activities. With Facebook, business people can build business relationships, grow the number of customers. Facebook keeps adding features and innovating consistently. Companies can utilize Facebook's features to reach audiences in various ways.

Gangadharbatla in Roberts (2010) states that social networking sites change the way advertisers reach consumers. Facebook features can be used to create and experiment in advertising activities. Every Facebook account, like a personal profile page, can write messages to the public and other users. Facebook applications can be in the form of photos, events, groups, videos, notes, links, and inboxes and write private messages to others.

Social media advertising has received significant attention since the introduction of the social networking site Facebook. Now Facebook followers are more than 1.1 billion, beneficial for businesses to carry out social media advertising activities. Advertisers are willing to invest large amounts of money in advertising activities to reach their target market. Facebook as social media offers a way to advertise by reaching certain markets, such as demographic factors, interests, hobbies, income (Barnes, 2014: 3).

Albertus Erwin Kusuma W, MSMEs D'Amensi Motor Accessory, business actors said, "I offer merchandise Yamaha Byson motorcycle accessories through the hobby community on Facebook. The way to target the Byson motorcycle enthusiast community segment is to create an Albert D'Amensi sales account and display Yamaha Byson motorcycle accessory advertising content to your Byson Photo Display Group account. The group account is a collection of people who have the same fun and hobbies in beautifying Yamaha Byson motorbikes. In the group there was a discussion giving comments, giving recommendations to each other. As in the narration of the advertisement conveyed by Setya Hadi Wibawa, "maybe there is someone who wants to look for Mas, this is OQ, I want to sell, the conditions are still smooth, hehehe". Agus Irawan commented: "How much is it ??" Trie Vanjoel: "he sinini is suitable or not" Answered Setya Hadi Wibawa: "suitable Mbah haha, neat Mbah only needs to be cut a bit mogelok hahaha".

\section{CONCLUSION}

The picture of successful social media to advertise for MSMEs is through 
social media which have sites with hundreds of thousands and even millions of members connected on websites, blogs, Google, Youtube, Whatsapp, Facebook and Instagram. Advertising content on social media must pay attention to photo works that have an appeal, both in terms of photography techniques, photo stories in the concept of ad photography, photo works must be protected with (watermark) so that it is not easy to plagiarize, in making video advertisements on YouTube there are several alternative ways, i.e. by making simple videos, as many videos as possible, professional videos, using keywords (keywords) or in the title of the advertisement made as much as possible that is similar to the product being sold. To attract a brand of goods, in photo or video messages a strategy for using endorsement and testimony is required. Consciousness and consideration of consumers in making purchases occur in a social media ecosystem that is interrelated and interacts with each other.

\section{REFERENCES}

Balcazar, Yolanda Suarez., Fabricio E. Balcazar, Tina Taylor Ritzler, E. G. I. (2008). Capacity Building and Empowerment: Gateways: International Journal of Community Research and Engagement. Diambil dari http://epress.lib.uts.edu.au/ojs/ index.php/ijcre/article/viewArticle/626

Barnes, J. (2014). Social Advertising Using Facebook Some Experimental Result Using Duck Dynasty Ads to Promote Rural Touristm in Mississipi. Dallas,TX.

Boyd, D. M., \& Ellison, N. B. (2008). Social Network Sites: Definition, History, and Scholarship. Journal of ComputerMediated Communication. https://oi. org/10.1111/j.1083-6101.2007.00393.x

Bunina, T. (2013). Fashion blogger's methods of communication of consumption experience. Aarhus. Diambil dari https://www.scribd. com/document/332567317/Fashion-
Blogger-s-\%0 A Methods-ofCommunication $\% 0 \mathrm{~A}$

Davis, Harold, D. I. (2006). Google advertising tools. Sebastopol: Gravenstein Highway North. https:// doi.org/10.5860/choice.43-6567

Denzin, N. K., \& Lincoln, Y. S. (1994). Introduction: Entering the field of qualitative research. Handbook of Qualitative Research.

Gilmore, A., Carson, D., \& Grant, K. (2001). SME marketing in practice. Marketing Intelligence \& Planning, 19(1), 6-11. https://doi. org/10.1108/02634500110363583

Govender, J. P. (2013). Using the Internet to market small, medium and micro enterprises in a developing economy. Problems and Perspectives in Management.

Holmbom, M. (2015). The YouTuber The Future of Advertising Merging with Entertainment. Aspatore Books. Diambil dari https://www.divaportal. org/s mash/get/diva 2:825044/ FULLTEXT01.pdf

Jamaluddin, I., Rafidah, C. R., Nurul, F. S., Roszaini, C. N., \& Li, Z. Y. (2014). Positive Impact of Smartphone Application: Whatsapp \& Facebook for Online Business. International Journal of Scientific and Research Publications, 4(12), 1-4. Diambil dari http://citeseerx.ist.psu.edu/viewdoc/ download? doi=10.1.1.663.5992 $\&$ rep $=$ rep1\&type $=$ pdf

Krishnamurthy, R. (2018). Social Media as a Marketing Tool. https://doi. org/10.4018/978-1-5225-6064-7.ch011

Mardikanto, T. (2010). Sistem Penyuluhan Pertanian. Surakarta: Sebelas Maret University Press. https://doi. org/10.2174/138920312803582960

Mon, G. E. (2013). Advertising and Promotion in Social media. Ocean/Corb.

Moustafa, K. (2016). Internet and Advertisement. Science and Engineering Ethics, 22(1), 293-296. https://doi.org/10.1007/s11948-0159647-z

Oji, O. N. E., Iwu, C. G., \& Haydam, N. (2017). The use of social media marketing strategies by SMMEs in the 
hospitality sector in Cape Metropole, South Africa. African Journal of Hospitality, Tourism and Leisure.

Plummer, Joseph, Steve Rappaport, Taddy Hall, R. B. (2001). Online Advertising Playbook, Proven Strategies and Tested Tactics. John Wiley \& Sons, Inc.

Prabowo, A. and K. A. (2017). Media Sosial Instagram Sebagai Sarana Sosialisasi Kebijakan Penyiaran Digital. Jurnal Aspikom.

Roberts, K. K. (2010). Privacy and Perceptions : How Facebook Advertising Affects its Users. Elon Journal of Undergraduate Research in Communications.

Royan, F. . (2004). Marketing Celebrities. Selebriti dalam Iklan dan Strategi Selebriti Memasarkan Diri Sendiri. Jakarta: PT. Elex Media Komputindo.

Springer, P. (2007). Ads to icons: how advertising succeeds in a multimedia age. Choice Reviews Online. https:// doi.org/10.5860/choice.47-3269

Suryono, J, Astuti, P. I., Rahayu, N. T., \& Widayati, M. (2019a). ( Caricature of Outdoor Media Political Advertising Dont Buy Cats in Sacks ) kota Surakarta . Iklan Politik Media Luar Ruang Honda Hendarto menarik untuk verbal peribahasa Jangan Membeli Kucing Politik Media Luar Ruang lainnya biasanya Politik Media Luar, 12(1), 46-60.
Suryono, J, Astuti, P. I., Rahayu, N. T., \& Widayati, M. (2019b). Superlative Sign Typology of Curahan Hati - Harapan Warga Jakarta Political Advertising Video. In 2nd Workshop on Language, Literature and Society for Education; Solo. https://doi.org/10.4108/eai.21-122018.2282712

Suryono, Joko. (2013). Model Media Iklan Potensial Yang Tepat Sasaran Produk Unggulan UKM. Profetik, 6(2), 17-26.

Sutopo, H. B. (2006). Metodologi Penelitian Kualitatif: Dasar Teori dan Terapannya dalam Penelitian.

Sutyowati, Y. (2016). “ Peningkatan Kapabilitas UMKM Dalam Mewujudkan UMKM Naik Kelas ." Surakarta: Di Gedung Pusdiklat UNS.

Thornley, P. (2014). Examining the Role of Bloggers in the Fashion Industry, A Public Relations Strategy for New Designers. Diambil dari digitalcommons. calpoly.edu/cgi/viewcontent. cgi?article $=1074 \&$ context $=$ joursp

Tungate, M. (2007). Ad Land A Global History of Advertising.

Yuliani, R., \& Dida, S. (2018). Personal Branding Selebritas dan Bisnis Online Shop. Mediator: Jurnal Komunikasi, 11(1), 10-19. https://doi.org/10.29313/ mediator.v1li1.3617 